\title{
Haematological profile of healthy adult blood donors in Mwanza, Tanzania
}

\author{
ALLY FAYA ${ }^{1}$, MWESIGE CHARLES ${ }^{2}$, LARRY F. SEMBAJWE ${ }^{3}$ and HARUNA I. DIKA ${ }^{1^{*}}$ \\ ${ }^{1}$ Catholic University of Health and Allied Sciences, Mwanza, Tanzania \\ ${ }^{2}$ Bugando Medical Centre, Mwanza, Tanzania \\ 3 Makerere University, Kampala, Uganda
}

\begin{abstract}
Background: While it is customary to apply the same haematological reference ranges, variations exist between populations. This study was conducted to determine hematologic profiles among a local population of north-western Tanzania.

Methods: This was a cross sectional study, which enrolled healthy adult blood donors in Mwanza, Tanzania. Collected blood samples were put in EDTA-coated tubes and haematological indices were determined using Auto Hematology-Analyzer. Results are summarized in medians plus 95\% interquartile ranges and compared using either Mann-Whitney $U$ or Kruskal-Wallis tests depending on appropriateness. Results: A total of 163 ( 143 males and 20 females) adult healthy blood donors (median age $=31$ years) were enrolled. We found a median haemoglobin level of $15.1 \mathrm{~g} / \mathrm{dL}[10.5-23.8]$, erythrocytes of $5.3 \times 10^{6} / \mu \mathrm{L}[4.1-8.3$ $\mathrm{x} 10^{6}$ ], haematocrit of $44.0 \%$ [32.4-71.4], total leucocytes of 4300 cells/ $\mu \mathrm{L}$ [1700-8500], lymphocytes $1700 / \mu \mathrm{L}$ [800-3000], neutrophils 2100/ $\mathrm{L}$ [300-5300]; mid-sized cells (monocytes, eosinophils and basophils) of $400 / \mu \mathrm{L}[100-1400]$ and platelets of $194 \times 10^{3} / \mu \mathrm{L}\left[55.2-379.0 \times 10^{3}\right]$. We observed significantly higher haemoglobin level $(P=0.017)$ as well as erythrocytes $(P=0.012)$ and haematocrit $(p=0.006)$ among males than females.

Conclusion: The percentile range (2.5\%-97.5\%) which can be used to determine the higher and lower values of haematological profile normal ranges for most indices differ from Western adopted reference values. Therefore, we recommend a large study to establish local normal hematologic reference values.
\end{abstract}

Keywords: haematological indices, reference ranges, adult, Tanzania

\section{Introduction}

Haematological profile reference ranges used to diagnose blood disorders among patients with diverse ancestral origins and who are exposed to different environmental conditions are known to vary by ethnicity, altitude, age and sex (Adam \& Strang, 1975; Bain \& England, 1975; Taylor et al., 1997; Beall \& Reichsma, 1984; Moore \& Sun, 1990; Marwaha et al., 1992; Waalen et al., 2002; Garruto et al., 2003; Beutler \& West, 2005; Butkiewics et al., 2006). For most of haematological indices, genetic characteristics of populations are believed to account for the majority of the variations (Dal Colletto et al., 1993). Thus, there are differences between "normal" values obtained from different populations. Studies in the United States of American showed that African-Americans have lower average haemoglobin level, haematocrit, and mean corpuscular volume than their Caucasian compatriots of the same age, sex and living in the same environment (Reed \& Diehl, 1991; Perry et al., 1992; Johnson-Spear \& Yip, 1994; Beutler \& West, 2005). A number of studies in Qinghai-Tibetan Plateau demonstrated the influence of ethnicity on hematologic parameters; suggesting an ethnic difference in the erythropoietic response to high altitudes (Moore \& Sun, 1990; Zhuang et al., 1993; Curran et al., 1997; Garruto et al., 2003).

Due to variations in haematological profiles, scholars have suggested consideration of ethnicity and other local factors in selecting appropriate cut-off-values of haematological indices (Reed \& Diehl, 1991; Perry et al., 1992; Johnson-Spear \& Yip, 1994). Such consideration is of great importance because choosing unrelated "normal ranges" may lead to a false diagnosis, unnecessary additional investigations, as well as extra treatment costs (Reed \& Diehl, 1991). When these ranges are derived from one population and then applied to another, unnecessary investigations of seemingly aberrant laboratory results may be the consequence.

\footnotetext{
*Correspondence E-mail: hdika2001@yahoo.co.uk
} 
Despite the recommendations to consider ethnicity and other local factors in selecting appropriate hematologic-reference ranges, there dearth of information on the normal haematological reference values, which are locally derived from Tanzania population. The current reference ranges for haematological indices, which are used in the country for diagnosing blood disorders were derived from American and European population and set by World Health Organization (WHO) over five decades ago (WHO, 1968; 2001). These reference values, which are in use, may not be normal for Tanzanian population. Therefore, the objective of this study was to determine the normal haematological profiles of healthy adult blood donors at Bugando Medical Centre in Mwanza, Tanzania.

\section{Material and Methods}

\section{Study design and setting}

A cross sectional study was conducted at Bugando Medical Centre (BMC) from June to July 2017. $B M C$ is a consultant and teaching referral hospital, in Mwanza City, Tanzania. The city is located on the southern shores of Lake Victoria in the north-western part of Tanzania. BMC serves a catchment population of about 13 million people from six regions of Tanzania, namely Mwanza, Kagera, Shinyanga, Mara, Kigoma and Tabora.

\section{Study subjects and sampling}

The study involved subjectively healthy blood donors who donated blood at BMC. Only native black Tanzanians were available for blood donations and hence enrolled in this study. By default of blood donation criteria, pregnant women did not participate in this study. Subjects known or who were clinically identified to have acute or chronic illness, or having symptoms and/or signs of anaemia and those on hematinic drugs were excluded from this study. Samples from subjects who tested positive for HIV or Hepatitis B and C or Syphilis were excluded from this study.

Minimum sample size was determined using a formula: $n=N / 1+N(e)^{2}(Y a m a n e, 1973)$ with $95 \%$ confidence interval level. Where: $\mathrm{n}=$ minimum required sample size, $\mathrm{N}=$ number of blood donors in one month (which was estimated to be 250 ) and e = allowable error (\%) which was set as 0.05 . Substituting in the formula: $n=250 / 1+250 *(0.05)^{2}=153.8$. Thus, minimum of 154 blood donors were required to be enrolled in the study. A consecutive sampling procedure was used to enrol subjects who met the inclusion criteria.

\section{Data collection}

Socio-demographic data of subjects who voluntarily agreed to participate in the study were recorded. In addition to the blood that was taken in plane tubes for serological analysis (to rule out HIV, Hepatitis B and C, and Syphilis), $5 \mathrm{ml}$ of blood samples were collected immediately following the donation and put in ethylene-diamine-tetra-acetic acid (EDTA) coated tubes. Blood was stored at room temperature before determination of haematological indices, which was done within 24 hours. Haematological indices were measured using Mindray BC-3200 Auto Hematology Analyzer (Mindray, Absolute Medical Inc., Garnerville, NY 10923).

\section{Data analysis}

Categorical data were cleaned, edited, coded and entered into Microsoft Excel together with continuous data. Data were then exported to Statistical Package for the Social Sciences (SPSS) software version 20 for analysis. Haematological parameters are expressed in medians plus interquartile ranges (IQR) and summarized in tables. Comparison of the haematological indices by sex and residence region was done using Mann-Whitney $U$ test while comparison by age groups was done using Kruskal-Wallis test. Statistical significance levels were fixed at $p$-value of 0.05 . 


\section{Ethical considerations}

Ethical clearance was sought and provided by the joint Catholic University of Health and Allied Sciences and BMC Research Ethics and Review Committee. Permission to collect data was granted by BMC administration. Written informed consents were sought from all the blood donors who voluntarily agreed to participate in the study.

\section{Results}

A total of 163 subjectively healthy blood donors aged 18-59 years (median age of 31 years) participated in this study. Among these, 143 (87.7\%) were males and 20 (12.3\%) were females. Majority, 144 (88.3\%) of the participants were from Mwanza region and 19 (11.7\%) were from other regions. Haematological indices-medians and 95\% interval (2.5-97.5 IQR) are summarized in Table 1. Males had significantly higher haemoglobin $(\mathrm{Hb})$ concentration as well as erythrocyte (RBC) count and haematocrit than females. Median $\mathrm{Hb}$ concentration of males and females were 15.2 $\mathrm{g} / \mathrm{dl}$ and $13.8 \mathrm{~g} / \mathrm{dl}$, respectively $(P=0.017)$. Median RBC count for males was significantly higher among males $\left(5.3 \times 10^{12} / \mathrm{L}\right)$ than females $\left(4.8 \times 10^{12} / \mathrm{L}\right)(\mathrm{P}=0.012)$. Median haematocrit value of males was significantly higher $(44.4 \%)$ than that of females $(40.1 \%)(P=0.006)$. The rest of haematological parameters did not significantly differ between the males and females (Table 1 ).

Table 1: Haematological Indices of Blood Donors at Bugando Medical Centre (BMC)

\begin{tabular}{|c|c|c|c|c|c|c|}
\hline \multirow{3}{*}{$\begin{array}{l}\text { Haematological Indices } \\
\text { Hb concentration (g/dl) }\end{array}$} & \multicolumn{5}{|c|}{ Median and $95 \%$ percentile Intervals } & \multirow{3}{*}{$\begin{array}{l}\text { P value } \\
0.017\end{array}$} \\
\hline & \multicolumn{3}{|c|}{$\begin{array}{l}\text { Males and Females Combined }(N= \\
163)\end{array}$} & \multirow{2}{*}{$\begin{array}{l}\text { Males } \\
(\mathrm{N}=143) \\
\text { Median } \\
15.2\end{array}$} & \multirow{2}{*}{$\begin{array}{l}\text { Females } \\
(\mathrm{N}=20) \\
\text { Median } \\
13.8\end{array}$} & \\
\hline & 15.1 & 10.5 & 23.8 & & & \\
\hline $\operatorname{RBC}\left(\times 10^{6} / \mu \mathrm{L}\right)$ & $5 \cdot 3$ & 4.1 & 8.3 & $5 \cdot 3$ & 4.8 & 0.012 \\
\hline Haematocrit (\%) & 44.0 & 32.4 & 71.4 & 44.4 & 40.1 & 0.006 \\
\hline $\operatorname{MCV}(f l)$ & $83 \cdot 3$ & 69.1 & $97 \cdot 3$ & 83.6 & 82.4 & 0.504 \\
\hline $\mathrm{MCH}(\mathrm{pg})$ & 28.2 & 22.0 & 33.8 & 28.4 & 27.4 & 0.222 \\
\hline $\mathrm{MCHC}(\mathrm{g} / \mathrm{L})$ & 34.0 & 29.4 & 37.9 & 33.8 & $34 \cdot 3$ & 0.840 \\
\hline RDW & 13.9 & 12.3 & 16.2 & 13.8 & 14.0 & 0.458 \\
\hline Total WBC $\left(\times 10^{3} / \mu \mathrm{L}\right)$ & $4 \cdot 3$ & 1.7 & 8.5 & $4 \cdot 3$ & 4.8 & 0.093 \\
\hline 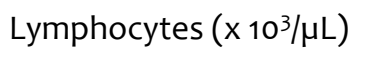 & 1.7 & 0.8 & 3.0 & 1.7 & 1.9 & 0.150 \\
\hline Lymphocytes \% & 40.9 & 21.3 & 78.2 & 40.9 & 40.1 & 0.236 \\
\hline Neutrophils $\left(\times 10^{3} / \mu \mathrm{L}\right)$ & 2.1 & 0.3 & $5 \cdot 3$ & 2.0 & 2.2 & 0.083 \\
\hline Neutrophils \% & $47 \cdot 3$ & 14.2 & 70.1 & 47.1 & 50.1 & 0.121 \\
\hline 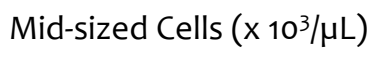 & 0.4 & 0.1 & 1.4 & 0.4 & 0.5 & 0.579 \\
\hline Mid-cells \% & 10.4 & 6.2 & 29.0 & 10.6 & 10.1 & 0.398 \\
\hline Platelets $\left(\times 10^{3} / \mu \mathrm{L}\right)$ & 194.0 & 55.2 & 379.0 & 193.0 & $225 \cdot 5$ & 0.165 \\
\hline $\operatorname{MPV}(f L)$ & 9.0 & 7.6 & 10.8 & 9.0 & 9.2 & 0.224 \\
\hline PDW & $15 \cdot 9$ & 15.1 & 17.1 & $15 \cdot 9$ & 15.8 & 0.100 \\
\hline $\mathrm{PCT}(\%)$ & 0.2 & 0.1 & 0.3 & 0.2 & 0.2 & 0.119 \\
\hline
\end{tabular}

Key: $\mathrm{Hb}=$ Haemoglobin, $\mathrm{RBC}=$ red blood cells (erythrocytes), $\mathrm{MCV}=$ mean corpuscular volume, $\mathrm{MCH}=$ mean corpuscular haemoglobin, $\mathrm{MCHC}=$ mean corpuscular haemoglobin concentration, RDW = red cell distribution width, WBC $=$ white blood cells (leucocytes), mid-sized cell = monocytes, eosinophils and basophils), MPV = mean platelet volume, $\mathrm{PDW}=$ platelet distribution width, $\mathrm{PCT}=$ plateletcrit. $\mathrm{P}$ values are for males and females comparisons of medians 
Apart from mid-sized cell-(monocytes, eosinophils and basophils) counts which were significantly higher ( $p=0.029)$ among blood donors aged 18-20 years compared to other age groups, other haematological indices did not significantly vary with age (Table 2). Comparison between participants from Mwanza region and those from other regions showed no statistically significant difference in all hematologic indices measured.

Table 2: Haematological profile of blood donors by age

\begin{tabular}{|c|c|c|c|c|c|c|}
\hline \multirow[t]{2}{*}{ Haematological Indices } & \multicolumn{6}{|c|}{ Medians across age groups (years } \\
\hline & $\leq 20$ & $21-30$ & $31-40$ & $41-50$ & $\geq 51$ & P-value \\
\hline Hb concentration (g/dl) & 13.8 & 14.7 & 15.70 & 15.2 & 15.1 & 0.085 \\
\hline $\operatorname{RBC}\left(\times 10^{6} / \mu \mathrm{L}\right)$ & 4.8 & $5 \cdot 3$ & $5 \cdot 38$ & 5.2 & 4.9 & 0.264 \\
\hline Haematocrit (\%) & $39 \cdot 3$ & 44.1 & $45 \cdot 30$ & 45.1 & 42.3 & 0.078 \\
\hline $\operatorname{MCV}(\mathrm{fl})$ & 82.5 & 82.9 & 85.2 & 84.7 & 82.3 & 0.361 \\
\hline $\mathrm{MCH}(\mathrm{pg})$ & 28.20 & 28.1 & 28.90 & 27.8 & 30.2 & 0.104 \\
\hline $\mathrm{MCHC}(\mathrm{g} / \mathrm{L})$ & 34.90 & 34.0 & 34.10 & 32.5 & 35.0 & 0.065 \\
\hline RDW & 14.0 & 13.8 & 13.7 & 14.1 & $13 \cdot 3$ & 0.568 \\
\hline Total WBC $\left(\times 10^{3} / \mu \mathrm{L}\right)$ & 5.1 & $4 \cdot 4$ & 4.20 & 4.2 & 3.8 & 0.098 \\
\hline 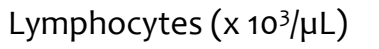 & 1.8 & 1.7 & 1.70 & 1.7 & 1.4 & 0.596 \\
\hline Neutrophils $\left(\times 10^{3} / \mu \mathrm{L}\right)$ & 2.9 & 2.0 & 2.10 & 1.8 & 2.0 & 0.152 \\
\hline Mid-sized Cells (x 103/ $/ \mu \mathrm{L})$ & 0.6 & 0.4 & 0.40 & 0.5 & 0.4 & 0.029 \\
\hline Platelets $\left(\times 10^{3} / \mu \mathrm{L}\right)$ & 177.0 & 203.5 & 189.0 & 201.0 & 201.0 & 0.481 \\
\hline MPV (fL) & 8.5 & 9.0 & 9.2 & 9.0 & $9 \cdot 5$ & 0.581 \\
\hline PDW & 15.7 & 16.0 & 16.0 & $15 \cdot 9$ & 16.0 & 0.220 \\
\hline PCT (\%) & 0.2 & 0.2 & 0.2 & 0.2 & 0.2 & 0.588 \\
\hline
\end{tabular}

$\mathrm{P}$ values are for age groups comparisons of medians

\section{Discussion}

In this study, we determined haematological profile using adult healthy Tanzanian blood donors. The use of population specific haematological reference in diagnosing blood disorders or follow up of treatments is of great importance (Reed \& Diehl, 1991; Perry et al., 1992; Johnson-Spear \& Yip, 1994), because choosing unrelated reference values may lead to a false diagnosis and unnecessary additional investigation and treatment costs (Reed \& Diehl, 1991). When reference ranges derived from one population are applied to another population, unnecessary investigations of seemingly aberrant laboratory results may be the consequence. For instance in a study in the USA about one-fifth of the healthy African-American women would have been classified as anaemic using the general population's reference range (Beutler \& West, 2005).

The medians of all haematological indices, which were determined in the present study, are within the reference ranges currently used in Bugando Medical Centre and Tanzania in general. However, the acceptable lower limits (2.5 percentile) of total WBC count, absolute neutrophil number, neutrophil percentage, haemoglobin concentration, RBC count, haematocrit and platelet count derived from the present study are lower than the current recommended reference ranges (Hoffbrand \& Moss, 2011). On the other hand, the upper limits (97.5 percentile) of lymphocyte percent, mid-sized cells percentage, Hb level, RBC count and haematocrit are higher than the current recommended reference ranges.

The Hb level, RBC counts and haematocrit were observed to be higher among male blood donors than female donors. Studies elsewhere have also reported that men and women have different mean haemoglobin levels in healthy individuals; and it is most likely to be associated with sex hormones. The higher Hb levels, RBC counts and haematocrit in males than in females are consistent with results from other studies worldwide including other African countries (Usman et al., 2007; Kibaya et al., 2008; Hoffbrand \& Moss, 2011; Miri-Dashe et al., 2014; Tekkeșin et al., 2014; Murphy, 2014; Yalew et al., 2016). Similar observations were also made in studies in other parts of Tanzania (Saathoff et al., 2008; Buchanan et al., 2010). The difference in the Hb, 
RBC counts and haematocrit among females and males is likely to be due to the effect of testosterone in boosting these parameters in males than in females (Shahidi, 1973; Hugh Rushton et al., 2001; Hall, 2006). Relatively higher leucocyte count among female blood donors compared to males supports the observation by Bain \& England (1975) in a study which involved healthy Caucasian hospital staff.

While a number of haematological parameters described in the present study differ from recommended reference intervals which are adopted from studies in western countries (Hoffbrand \& Moss, 2011), the findings are similar to those from another study in Mbeya, southern-western Tanzania (Saathoff et al., 2008) and other African countries (Kibaya et al., 2008; Dosoo et al., 2012; Miri-Dashe et al., 2014; Yalew et al., 2016). This might be a reflection of the similarities between the ethnic groups of people involved in these particular studies. Exception on the similarities is on $\mathrm{Hb}$ levels, which were noted to be low in studies done in Kenya and Ghana as well as relatively low RBC count noted in Ghana (Koram et al., 2007; Kibaya et al., 2008; Dosoo et al., 2012). Low levels of $\mathrm{Hb}$ and RBC count in the Kenya and Ghana studies can be explained by the differences in populations which were included in studies. In our study, we enrolled selectively healthy individuals while Kenya and Ghana studies randomly enrolled individuals from general community. Anaemia, particularly nutritional anaemia is known to be common in subSahara African communities (Ramakrishnan, 2002; Leenstra et al., 2004) and can affect the haematological parameter especially $\mathrm{Hb}, \mathrm{RBC}$ count and haematocrit.

In conclusion, the findings of this study are similar to those of other studies in Tanzania and others in African countries than to the conventional reference values adopted from the Western populations. The lower and upper limits for a number of indices are outside the recommended reference ranges. Due to small number of participants particularly females, we recommend a large scale local population studies to determine other haematological parameters.

\section{Acknowledgements}

We acknowledge the support from BMC Main Laboratory, particularly the haematology section staff for their cooperation during data collection.

\section{Conflict of Interest}

Authors have no conflict of interest to report.

\section{References}

Bain, B.J. \& England, J. (1975) Normal haematological values: sex difference in neutrophil count. British Medical Journal 1:306-309.

Beall, C.M. \& Reichsman, A. (1984) Hemoglobin levels in a Himalayan high altitude population. American Journal of Physical Anthropology 63: 301-306.

Beutler, E. \& West, C. (2005) Hematologic differences between African-Americans and whites: the roles of iron deficiency and $a$-thalassemia on hemoglobin levels and mean corpuscular volume. Blood 106: 740-745.

Buchanan, A.M., Muro, F.J., Gratz, J., Crump, J.A., Musyoka, A.M., Sichangi, M.W., Morrissey, A.B., M'rimberia, J.K., Njau, B.N. \& Msuya, L.J. (2010) Establishment of haematological and immunological reference values for healthy Tanzanian children in Kilimanjaro Region. Tropical Medicine \& International Health 15: 1011-1021.

Butkiewicz, A.M., Kemona, H., Dymicka-Piekarska, V., Matowicka-Karna, J., Radziwon, P. \& Lipska, A. (2006) Platelet count, mean platelet volume and thrombocytopoietic indices in healthy women and men. Thrombosis Research 118: 199-204. 
Curran, L.S., Zhuang, J., Sun, S.F. \& Moore, L.G. (1997) Ventilation and hypoxic ventilatory responsiveness in Chinese-Tibetan residents at 3,658 m. Journal of Applied Physiology 83: 2098-2104.

Dal Colletto, G., Fulker, D., Barretto, O. d. O. \& Kolya, M. (1993) Genetic and environmental effects on blood cells. Acta Geneticae Medicae et Gemellologiae Supplementum 42: 245-252.

Dosoo, D.K., Kayan, K., Adu-Gyasi, D., Kwara, E., Ocran, J., Osei-Kwakye, K., Mahama, E., AmengaEtego, S., Bilson, P. \& Asante, K.P. (2012) Haematological and biochemical reference values for healthy adults in the middle belt of Ghana. PLoS One 7: e36308.

Garruto, R.M., Chin, C., Weitz, C.A., Liu, J.C., Liu, R.L. \& He, X. (2003) Hematological differences during growth among Tibetans and Han Chinese born and raised at high altitude in Qinghai, China. American Journal of Physical Anthropology 122: 171-183.

Hall, J.E. (2006) Guyton and Hall Textbook of Medical Physiology, $11^{\text {th }}$ ed. Elsevier Saunders.

Hoffbrand, A.V. \& Moss, P.A. (2011). Essential haematology, John Wiley \& Sons.

Hugh Rushton, D., Dover, R., Sainsbury, A.W., Norris, M.J., Gllkes, J.J.H., Ramsay, I.D. (2001) Why should women have lower reference limits for haemoglobin and ferritin concentrations than men? BMJ 322(7298): 1355-1357.

Johnson-Spear, M.A. \& Yip, R. (1994) Hemoglobin difference between black and white women with comparable iron status: justification for race-specific anemia criteria. The American Journal of Clinical Nutrition 60: 117-121.

Kibaya, R.S., Bautista, C.T., Sawe, F.K., Shaffer, D.N., Sateren, W.B., Scott, P.T., Michael, N.L., Robb, M.L., Birx, D.L. \& de Souza, M.S. (2008) Reference ranges for the clinical laboratory derived from a rural population in Kericho, Kenya. PLoS One 3: e3327.

Koram, K., Addae, M., Ocran, J., Adu-Amankwah, S., Rogers, W. \& Nkrumah, F. (2007) Population based reference intervals for common blood haematological and biochemical parameters in the Akuapem north district. Ghana Medical Journal 41.

Leenstra, T., Kariuki, S. K., Kurtis, J. D., Oloo, A. J., Kager, P. A. \& ter Kuile, F. O. (2004) Prevalence and severity of anemia and iron deficiency: cross-sectional studies in adolescent schoolgirls in western Kenya. European Journal of Clinical Nutrition 58: 681.

Marwaha, R., Narang, A., Thusu, K., Garewal, G. \& Bhakoo, O. (1992) Routine hematological values in term newborns. Hemoglobin 16: 12-21.0.

Miri-Dashe, T., Osawe, S., Tokdung, M., Daniel, N., Choji, R.P., Mamman, I., Deme, K., Damulak, D. \& Abimiku, A.l. (2014) Comprehensive reference ranges for hematology and clinical chemistry laboratory parameters derived from normal Nigerian adults. PLoS One 9: e93919.

Moore, L.G. \& Sun, S. (1990) Physiologic adaptation to hypoxia in Tibetan and acclimatized Han residents of Lhasa. Hypoxia: the adaptation BC Dekker, Philadelphia PA.

Murphy, W.G. (2014) The sex difference in haemoglobin levels in adults - mechanisms, causes, and consequences. Blood Reviews 28: 41-47

Perry, G.S., Byers, T., Yip, R. \& Margen, S. (1992) Iron nutrition does not account for the hemoglobin differences between blacks and whites. Journal of Nutrition 122: 1417-24.

Ramakrishnan, U. (2002) Prevalence of micronutrient malnutrition worldwide. Nutrition Reviews 60: S46-S52.

Reed, W.W. \& Diehl, L.F. (1991) Leukopenia, neutropenia, and reduced hemoglobin levels in healthy American blacks. Archives of Internal Medicine 151: 501-505.

Saathoff, E., Schneider, P., Kleinfeldt, V., Geis, S., Haule, D., Maboko, L., Samky, E., Souza, M.D., Robb, M. \& Hoelscher, M. (2008) Laboratory reference values for healthy adults from southern Tanzania. Tropical Medicine \& International Health 13: 612-625.

Shahidi, N.T. (1973) Androgens and erythropoiesis. New England Journal of Medicine 289: 72-80.

Taylor, M., Holland, C., Spencer, R., Jackson, J., O'Connor, G. \& O'donnell, J. (1997) Haematological reference ranges for schoolchildren. Clinical \& Laboratory Haematology 19: 1-15. 
Tekkeşin, N., Bekoz, H. \& Tukenmez, F. (2014) The largest reference range study for hematological parameters from Turkey: A case control study. Journal of Clinical and Experimental Investigations 5.

Usman, K., Syed, Z.A. \& Rao, A.A. (2007) Reference range values of haematological parameters in healthy Pakistani adults. Pakistan Journal of Physiology 3:19-22.

Waalen, J., Felitti, V. \& Beutler, E. (2002) Haemoglobin and ferritin concentrations in men and women: cross sectional study. British Medical Journal 325: 137.

WHO (1968) Nutritional anaemias: report of a WHO scientific group [meeting held in Geneva from 13 to 17 March 1967]. Geneva: World Health Organization

WHO (2001) Iron deficiency anaemia: assessment, prevention and control, a guide for programme managers. Geneva: World Health Organization.

Yalew, A., Terefe, B., Alem, M. \& Enawgaw, B. (2016) Hematological reference intervals determination in adults at Gondar university hospital, Northwest Ethiopia. BMC Research Notes 9: 483 .

Yamane, T. (1973). Statistics: An Introductory Analysis. New York, Harper \& Row.

Zhuang, J., Droma, T., Sun, S., Janes, C., McCullough, R.E., McCullough, R.G., Cymerman, A., Huang, S.Y., Reeves, J.T. \& Moore, L.G. (1993) Hypoxic ventilatory responsiveness in Tibetan compared with Han residents of 3,658 m. Journal of Applied Physiology 74: 303311. 